\title{
Demand for Narcotics in Thailand and Policy Implications ${ }^{1}$

\author{
Renu Sukharomana ${ }^{1^{*}}$ \\ ${ }^{1}$ Institute of Social and Economic Sciences \\ Dhurakij Pundit University \\ ‘renu.suk@dpu.ac.th
}

\begin{abstract}
This paper examines that the demand for narcotic drugs based on Becker (1968) is one kind of rational behavior of human beings. The results from sampling surveys in eight provinces representing nationwide drug user/addicted in Thailand in 2014 shows that demand for narcotics (amphetamine, ice drug and marijuana) are price inelastic between -0.533 and -0.701 , as well as normal goods. The coefficients in models A and B are 0.192 and 0.0467 , respectively, so that an increase in income will raise demand for narcotics. In addition, factors affecting demand for narcotics are the age of user, age squared, friendship, family member relationship, social relationship, reason to drug use, risk behavior, and expected punishment. Some policy implications are proposed based on the demand side.
\end{abstract}

Keywords: Price Elasticity of Demand, Narcotics, Amphetamine, Ice Drug, Marijuana, Policy Implications, Thailand.

\section{Introduction}

The Thai government has announced the narcotics problem to be one of national importance. At present, the suppression has been conducted for a reduction of narcotics supply and providing opportunities for addicts in treatment programs. With an adoption of international concepts, the government defined narcotics addicts as patients to be treated by emphasizing on the belief that without addicts, there will be no dealers/traders. Reduction the number of addicts is the better way than suppression (Secretariat of the House of Senates, 2015). This paper is the initial research applying the economics concept ${ }^{2}$ in Thailand to study the behavior of narcotics addicts, which aims to provide related policy implications. The results are discussed in the following sections of the paper.

\section{Literature Review}

There are three possible factors determining crime committed in narcotic drug crime/user/ addicted, as follows: (1) psychological factor, (2) physiological and biological factors, and (3) socio-economic and cultural factors. Diagram 1 provides an understanding of drug behavior. Rational addiction theory developed by Becker and Murphy (1988) explain the major factors that determine the decision making of drug users and drug addicted, which is based on rational utility maximization. Violence in black market of narcotic drug in the USA has occurred since the Harrison Narcotic Act of 1914 (Trebach, 1982, Friedman, 1991, Goldstein, et al., 1989).

This paper modifies a number of lessons learned from abroad (Positive School; Social Structural Theory, Vold, 1958, Bonger, Climate of Motivation for Criminal Behavior; Social Process Theory, Sutherland, Siegel, 2000, Behavior Modeling, Travis Hirschi; Superego; Charls Murray and Louis Cox, 1979, Fejjrey Fagan and Alex Piquero, 2007, Developmental Influences on Recidivism among

\footnotetext{
${ }^{1}$ The author wishes to acknowledge the helpful comments and suggestions of Michael McAleer.

2 As economists agree that narcotics market is a special type of black market, but no one says that we could not estimate the demand for and the supply of goods in the black market (Becker, 1981). We will do so by using survey data and running the model of demand for narcotics (called "drugs" in this paper). The results are taken from "Supply of and Demand for Narcotics in Thailand and Policy Implications," Final report submitted to the Thailand Research Fund, April 2015.
} 
Adolescent Felony Offenders; Social and Psychological Problem, i.e. poverty; Economics of Crime by Becker, 1968) to develop questionnaires for the survey, as well as inc depth interviews.

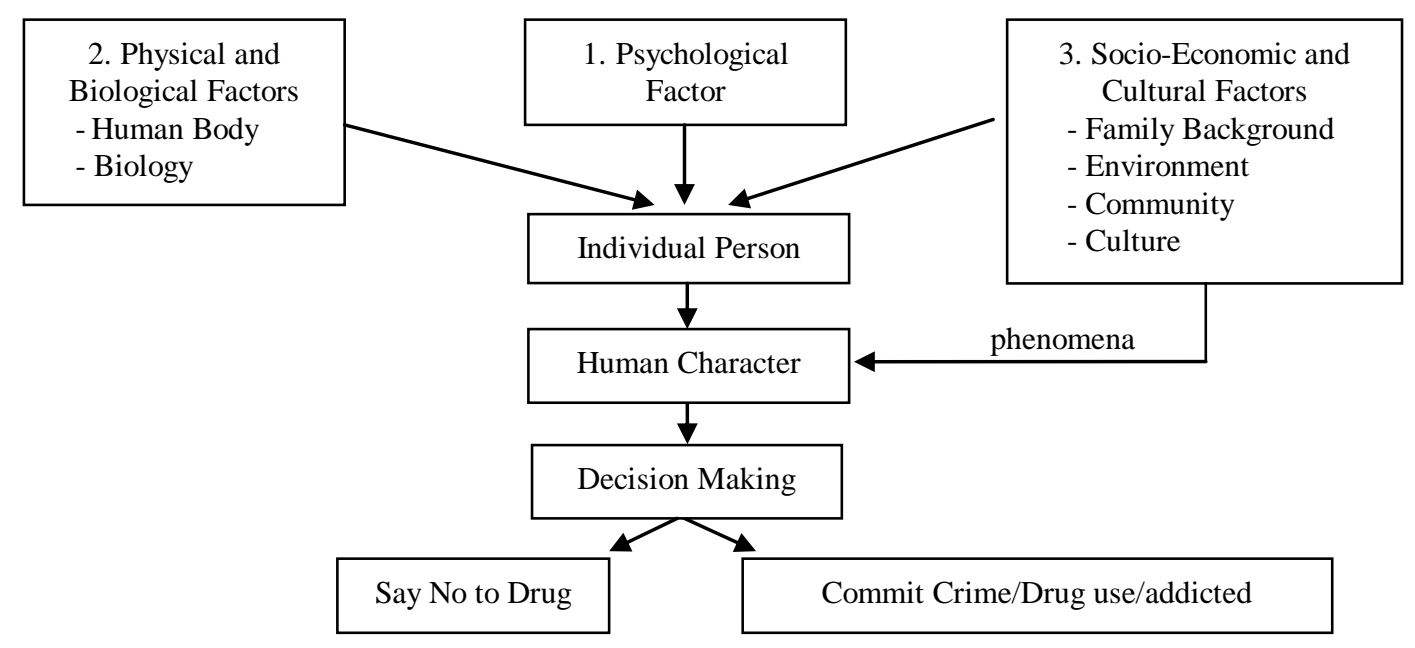

Diagram 1 Factors determining drug crime/user/ addicted

\section{Data Collection and Sample Survey}

Data collection and data analysis use a mixed method which allows double checking of reliability, not only using well-prepared questionnaires but also in-depth interviews. Both research tools are certified by the Office of The Commitee for Research Ethics (Social Sciences), Faculty of Social Sciences and Humanities, Mahidol University. The survey teams comprised 22 students, who are in the nursing program in the school of medicine under the supervision of staff. Very keen in-depth interviews and questionnaire survey in eight provinces represent nationwide from June to August, 2014. There was a total of 2,430 samples (Table 1), which cover two groups: First, 1,347 samples $\left(\mathrm{n}_{1}\right)$ of drug addicts in four big provinces; Chiangmai, Nakornrachsima, Songkla and Naratiwat, are withdrawn from the population of former drug addicts. In addition, some are under the special treatment program in four stations located in Nakornpathom Province under the Department of Juvenile Observation and Probation. Another program provided by the House of Detention and Training Center for Children and Youth are located in eight provinces representing the population nationwide. Second, 1,083 samples $\left(\mathrm{n}_{2}\right)$ of pedestrians: individual person whom are both randomly sampled, being interviewed in public spaces (such as streets, markets, public parks), and purposively selected via the snow-ball technique in the risked areas in eight provinces, as in the first group.

Table 1. Samples from Survey in Eight Provinces, Thailand, 2014

\begin{tabular}{|l|r|r|r|}
\hline \multirow{2}{*}{ Province } & \multicolumn{3}{|c|}{ Sample from Survey } \\
\cline { 2 - 4 } & $\begin{array}{c}\text { Drug User/ } \\
\text { DrugAddict }\end{array}$ & \multicolumn{1}{c|}{ Pedestrian } & Total \\
\hline 1.Chiangmai & 184 & 121 & 305 \\
\hline 2.Nakornrachsima & 195 & 197 & 392 \\
\hline 3.Chonburi & 287 & 103 & 390 \\
\hline 4.Bangkok & 410 & 428 & 838 \\
\hline 5.Songkhla & 173 & 100 & 273 \\
\hline 6.Naratiwat & 33 & 53 & 86 \\
\hline 7.Pattani & 33 & 46 & 79 \\
\hline 8.Yala & 32 & 38 & 2,433 \\
\hline \multicolumn{1}{|c|}{ Total } & 1,347 & 1,086 & 70 \\
\hline
\end{tabular}

Source: Renu Sukharomana et al., 2015. 


\section{Results}

4.1 Type of Narcotic Drug: Three types of drug use popular in Thaland among drug user/addicted, namely Amphetamine, Ice Drug, and Marijuana. The main reason why respondents in this study become drug addicted are as follows: $45.3 \%$ answer that they intend to try it at the very first time in their expereince, $40.5 \%$ say a friend convinced them to join their gang, and $3.1 \%$ see nearby people using drugs, which make them want to try it. Price of Amphetamine varies in different places, depends on transportation cost, way to access to drug dealer/delivery, among others. The distance from drug agency and / or place of drug production seem to be the major factors determining the market price. Chiangmai has probably the lowest price than other regions (see Table 2). The average number of amphetamine uses per day is 7 tablets, whereas ice drug and marijuana will be used one $g$ and one set per day, respectively. The average expenses of each particular type of drug are shown in the last row of Table 2, which gives some idea of the burben of expense per for drug user/addicted, of which marijuana is the smallest cost as compared with 1.5 times for amphetamine and 2.5 times for ice drug.

\subsection{Demand for Narcotic Drug}

4.2.1 Former Drug User/ Drug Addicted, $\left(\mathrm{n}_{1}=1,347\right.$; Model A): Demand for narcotics (amphetamine type) is small response to price between -0.533 to -0.701 . Narcotics (amphetamine type) is a normal good that addicts consume more as their incomes rise. Legal punishment is not a major factor to describe the behavior of drug user or the quantity of drug use. However, social sanction or impacts on people around them are factors that significantly decrease the number of drug users. Good relationship in family is more likely to significantly reduce drug addiction. Degree of risk aversion of the individual also determines the behavior of drug users, that is, the lower is the degree of risk aversion, the higher is the chance of drug use. Drug addicted with lower degree of risk aversion would be significant in drug trafficking.

Table 2. Region, Place and Price of Amphetamine, Ice Drug and Marijuana

\begin{tabular}{|c|c|c|c|}
\hline Region : Province & $\begin{array}{c}\text { Amphetamine } \\
\text { us } \$ \text { / tablet }\end{array}$ & $\begin{array}{l}\text { Ice Drug } \\
\text { us\$ / g* }\end{array}$ & $\begin{array}{c}\text { Marijuana } \\
\text { us } \$ \text { / set }\end{array}$ \\
\hline North: Chiangmai & 3.0 & 33.41 & 5.0 \\
\hline Northeastern : Nakormrachsima & 6.05 & 35.64 & 8.14 \\
\hline Central: Bangkok & 3.70 & 49.42 & 1.27 \\
\hline East: Cholburi & 3.50 & 41.62 & 1.65 \\
\hline South: Songkla & 5.22 & 52.57 & 2.95 \\
\hline Average price per unit & 4.16 & 47.02 & 1.64 \\
\hline Average amount used per day & 7 tablets** & $1 \mathrm{~g}$ & 1 set \\
\hline Average expense per day & $3.0-6.05$ & $33.41-52.57$ & 20.43 \\
\hline
\end{tabular}

Note: * one g approximately weighs of $0.8-1$ gram depends on drug dealer's package for retailed sale.

** The average number of used per day for amphetamine is 7 tablets whereas ice drug and marijuana will be one $\mathrm{g}$ and one set per day, respectively.

The exchange rate is 37 baht $=1$ us $\$$

4.2.2 Pedestrians, $\left(\mathbf{n}_{2}=\mathbf{1 , 0 8 6}\right.$; Model B): This study finds that of 1,086 in the sample, $14 \%$ is drug dealers/drug (with small amount of narcotic drug), $45 \%$ is drug users/addicteds ${ }^{3}$, whereas the rest of $41 \%$ is not associated with any kind of drug (say NO to drug, they said). Males are significantly more likely to be drug dealer/delivery to female. Age and education are statistically significantly factors determining drug users/addicts (group A), but not in pedestrians (group B). This might be because the respondents in group B are the samples from predestrians, whom the interviewers meet

\footnotetext{
${ }^{3}$ Since the main objective of this paper is to calculate the price elasticity of demand, which requires a large sample from the survey, the research team was suggested by the expert committee from the Thailand Research Fund to use the catchment area of the school of medicine located for students of the nursing program. The respondents in this study are located in Chiangmai, Chonburi, Songkla and Bangkok.
} 
them in public spaces. Some respondents might not reveal some parts of their information since they do not trust strangers, as shown in Table 3.

Table 3. Estimated Coefficients of Drug Users (Model A) and Pedestrians (Model B)

\begin{tabular}{|c|c|c|}
\hline \multirow[b]{2}{*}{ Variable } & Model A & Model B \\
\hline & $\begin{array}{l}\text { Coefficient } \\
\text { (S.E.) }\end{array}$ & $\begin{array}{l}\text { Coefficient } \\
\text { (S.E.) }\end{array}$ \\
\hline $\ln$ (price) & $\begin{array}{r}-0.533 * * * \\
(0.0471) \\
\end{array}$ & $\begin{array}{r}-0.701^{* *} \\
(0.3216) \\
\end{array}$ \\
\hline $\ln$ (income) & $\begin{array}{l}0.192 * * \\
(0.0754)\end{array}$ & $\begin{array}{c}0.0467 * \\
(0.0281)\end{array}$ \\
\hline Economic status & $\begin{array}{r}-0.169 * * \\
(0.0851) \\
\end{array}$ & \\
\hline Age & $\begin{array}{r}-0.0646 * * * \\
(0.0177) \\
\end{array}$ & $\begin{array}{r}0.00241 \\
(0.00697) \\
\end{array}$ \\
\hline Age squares & $\begin{array}{r}0.000770^{* *} \\
(0.000313)\end{array}$ & $\begin{array}{r}-5.14 \mathrm{e}-06 \\
(9.3 \mathrm{e}-05)\end{array}$ \\
\hline Marital Status $(0=$ Single $)$ & $\begin{array}{r}0.0892 \\
(0.0681) \\
\end{array}$ & $\begin{array}{l}0.0731 * \\
(0.0416) \\
\end{array}$ \\
\hline Employment Status & $\begin{array}{r}0.0470 \\
(0.0580) \\
\end{array}$ & $\begin{array}{r}-0.0787 \\
(0.0497) \\
\end{array}$ \\
\hline Family Relationship & $\begin{array}{r}0.00203 \\
(0.0249) \\
\end{array}$ & \\
\hline Friendship & $\begin{array}{r}-0.0215 \\
(0.0273) \\
\end{array}$ & \\
\hline Social Relationship & $\begin{array}{r}-0.00400 \\
(0.0216)\end{array}$ & \\
\hline Expected Punishment & $\begin{array}{r}7.93 \mathrm{e}-07 \\
(8.83 \mathrm{e}-06) \\
\end{array}$ & $\begin{array}{r}-1.78 \mathrm{e}-06 * * * \\
(6.84 \mathrm{e}-07) \\
\end{array}$ \\
\hline Age at First Use of Drug & $\begin{array}{r}-0.0124^{*} \\
(0.00672) \\
\end{array}$ & \\
\hline Education Background (0=No Edu) & $\begin{array}{r}0.266 \\
(0.229) \\
\end{array}$ & $\begin{array}{r}0.227 * * * \\
(0.0433) \\
\end{array}$ \\
\hline \multicolumn{3}{|l|}{ Reason of Drug Use ( $0=$ Intend to try) } \\
\hline 1.Accecpted by Friend & $\begin{array}{r}-0.435^{*} \\
(0.258)\end{array}$ & \\
\hline 2.Imitate People Nearby & $\begin{array}{r}-0.297 * \\
(0.156)\end{array}$ & \\
\hline \multicolumn{3}{|l|}{ Risk Behavior $(0=$ low risk $)$} \\
\hline 1.Gambling & $\begin{array}{r}0.132 \\
(0.0873) \\
\end{array}$ & $\begin{array}{r}0.0747 * \\
(0.0453) \\
\end{array}$ \\
\hline 2.Against the Traffic Light & $\begin{array}{r}0.133 * \\
(0.0686) \\
\end{array}$ & $\begin{array}{r}0.0663 \\
(0.0447) \\
\end{array}$ \\
\hline 3.Fast Driver & $\begin{array}{c}0.145 * * \\
(0.0626) \\
\end{array}$ & $\begin{array}{r}0.0839 * * \\
(0.0385) \\
\end{array}$ \\
\hline 4.Extreme Activities & $\begin{array}{r}0.00242 \\
(0.102) \\
\end{array}$ & $\begin{array}{r}0.0672 \\
(0.0798) \\
\end{array}$ \\
\hline Having Sex with Stranger without Condom & $\begin{array}{r}0.0202 \\
(0.117) \\
\end{array}$ & $\begin{array}{r}0.147 * \\
(0.0844) \\
\end{array}$ \\
\hline Constant & $\begin{array}{r}4.196 * * * \\
(0.446) \\
\end{array}$ & $\begin{array}{r}3.245 * * \\
(1.538) \\
\end{array}$ \\
\hline Samples & 1,008 & 1,066 \\
\hline $\mathrm{R}^{2}$ & 0.276 & 0.2237 \\
\hline
\end{tabular}

Source: Renu Sukharomna, et al., 2015, Tables 7 and 9, pp. 66 -69 and 73-76, respectively.

Note: Figure in each parenthesis indicates standard error (S.E.) $* * * 99 \%$ confidence interval, ** $95 \%$ confidence interval, * $90 \%$ confidence interval. 
4.3 Price Elasticity of Demand: The study sets up questions to ask each respondent how he/she changes behavior if the price changes. The results are given under two scenarios (Table 4).

Table 4. If Price Increases 100\% Versus If Price Decreases 100\%: What do you do?

\begin{tabular}{|c|c|c|c|c|c|c|c|c|}
\hline \multirow[t]{3}{*}{ Type of drug } & \multicolumn{4}{|c|}{$\begin{array}{l}\text { Scenario I: If price increases } 100 \% \\
\text { what do you do? }\end{array}$} & \multicolumn{4}{|c|}{$\begin{array}{l}\text { Scenario II: If price decreases } 100 \% \\
\text { what do you do? }\end{array}$} \\
\hline & \multirow{2}{*}{$\begin{array}{c}\mathrm{n} \\
\text { samples }\end{array}$} & Not buy* & No change & Buy less & \multirow{2}{*}{$\begin{array}{c}\mathrm{n} \\
\text { samples }\end{array}$} & \multirow{2}{*}{\begin{tabular}{|c|} 
Buy more \\
$\%$
\end{tabular}} & \multirow{2}{*}{$\frac{\text { No change }}{\%}$} & \multirow{2}{*}{$\frac{\text { Buy less }}{\%}$} \\
\hline & & $\%$ & $\%$ & $\%$ & & & & \\
\hline Amphetamine & 455 & 50.5 & 9.2 & 35.2 & 415 & 38.6 & 50.1 & 8.4 \\
\hline Ice drug & 121 & 41.3 & n.a. & 52.1 & 121 & 29.8 & 54.5 & 7.4 \\
\hline Marijuana & 73 & 24.7 & 20.4 & 16.4 & 73 & 34.8 & 52.2 & 8.7 \\
\hline
\end{tabular}

\subsubsection{Scenario I: As price goes up 100\%, what do you do?}

Amphetamine: Among the 455 respondents addicted to amphetamine, this is the majority group in the study. From their point of view, amphetamine and ice drug are necessarily good. It is hypothesised that they will not switch to another narcotic drug because drugs impact on their health, nerve and psychiy. In addition, one study shows that drug addicted mostly stick to their taste. When the price of amphetamine goes up, for example, $100 \%$ of the previous price, what will they do? We find that $59.2 \%$ of the respondents do not change their behavior (which means they still use the same amount), whereas $35.2 \%$ of the respondents use less amount of drug because they are not happy with the higher price. The figure of $59.2 \%$ is interesting as the results indicate the case of price-inelasticity of demand. This message is rather important for policy makers.

Ice drug: Among the 121 respondents, we find a similar behavior in this group of ice drug addicted. That is, $53.7 \%$ of the respondents do not change their behavior as they are already addicted. They still use the same amount as price goes up. Some respondents said that they cannot reduce the amount of drug as the price is more expensive. They are going to be sick and getting serious nervious symptoms as it impacts their brain and causes side effect and delusion. This group is sometimes called hard users. However, about $39.7 \%$ of the respondents will use less amount and substitute another kind of drug. This group might be light users.

Marijuana: Price of marijuana is relatively cheaper than another two kinds of narcotics, amphetamine and ice drug. No matter how price changes, their behavior still reflect itself as normal goods. Overall behavior of these types of narcotic drug users confirm normal goods, as well as necessary goods.

\subsubsection{Scenario II: As price goes down 100\%, what do you do ?}

We hypothesize that drug users/addicts are rational. Therefore, as price goes down, they should use more drugs to get higher utility level if narcotic drugs are normal goods. The results come out as shown in Table 4. Respondents from the survey are economic person with rational behavior because, as price decreases $100 \%$, they buy more for all three types of drugs; for example, if we consider amphetamine, about $38.6 \%$ buy more amphetamine, whereas only $8.4 \%$ buy less. However, it should be noted that respondents do not change the amount used for all types of drugs. This is because they are already addicted to each particular type then they have their own certain amount of drug use. No matter the price decreases, the amount of drug use will not change and/or change very little or buy other type of drug, as shown in the first scenario, which is in the column of not buy. This group is called price-inelasticity of demand. For the group that buys more when price is decreased, is called price-elasticity of demand.

\section{Conclusion and Policy Implication}

The study provides information on factors determining durg users/addicts. At least four issues are proposed, as follows: (1) To develop the education program, as well as to launch public relations program (PR), focus on harm of drug addicts among risk groups, which cover not only children, youth, and poor people living in slums, but also those who are studying at all levels of education, 
including those who are in the labor force and persons shown in the target area. (2) To reduce recidivism, school, college, and university, should organize special projects for children spending time together in detention on a field trip to Supermax Prison, as well as to allow children and youth to gain more experience of such prisoners detained. This project will help our children and youth to see examples of punishment for drug offenses. (3) It is possible to propose that the government should implement particular economic measures aimed at increasing direct income transfer payments, particularly to a group of drug addicts due to sensitivity and risk that they prefer taking some additional income paid for necessary expenses (food, medicine, clothes) to buy drugs. Such a transfer payment program for low incomes to stimulate economic growth would be considered an exceptional case for those who have been proved to be drug users, as well as drug addicts; and (4) the study shows the difficulty of a pedestrian/ purposive target group who earns less than 20,000 baht (approximately 550 US dollars) per month to be the target group of drug use /addicted. A clear identifying profile of one who is likely to be a drug user /addicted should be covered for further study on all income groups.

6. Recommendations for further research: (1) Policy making for drug legalization /decriminalization for some selected types of drug, that is, marijuana and maybe Kratom ${ }^{4}$. (2) Using social measures to initiate/ to develop strong relationships among family members and society that would become an effective way to reduce risk involvement of drug user/addicts. (3) Guidelines to improve performance of policemen to provide them to increase the probability to arrest the target groups, particularly of drug trafficking. This idea is based on the believe that it is better to increase the severity of the punishment. (4) Alternative ways of reduinge recidivism by job opportunities created by some specific government sectors as well as the private sector.

\section{References}

Becker, G. S., 1974. Economics of Crime and Punishment: An Economic Approach. National Bureau of Economic Research, Inc.

Becker, G. S., 1981. A Treatise on the Family. World Press.com.

Bonger, W. A., 1958. Punishment and Social Structure. In Theoretical Criminology. New York: Oxford University Press.

Fagan, F. \& Piquero, A., 2007, Developmental Influences on Recidivism among Adolescent Felony Offenders. Journal of Empirical Legal Studies.

Friedman, M., 1991. The Drug War. Interview with Milton Friedman on the Drug War.

Murray, C. \& Cox, L., 1979. Beyond Probation. in Criminology: Theories, Patterns, and Typologies by Siegel, 2015. Beverly Hills: Sage.

Sukharomana, R., et al., 2015. Supply of and Demand for Narcotics in Thailand and Policy Implications. Bangkok: Thailand Research Fund.

Sutherland, E. H., 1939, 1947. Social Control Theory. in Social Process Theories by Siegel, L. J., 2000 and Criminology by Siegel, $7^{\text {th }}$ ed., pp. 220-253.

Travis, H., 1995. Deviance: A Symbolic Interactionist Approach. in A Control Theory of Delinquency by Herman, Nancy J.

Trebach, A.S., 1982. The Heroin Solution, Michigan Law Review, Vol. 83, No. 4.

\footnotetext{
${ }^{4}$ Kratom is a tropical plant that can be found in common and used as ingredients in some menus in southern Thailand.
} 